\title{
Physical Activity in Liver Transplantation: A Patient's and Physicians' Experience
}

\author{
Lara Beekman · Annalisa Berzigotti (iD - Vanessa Banz
}

Received: July 27, 2018 / Published online: October 16, 2018

(C) The Author(s) 2018

\begin{abstract}
Liver transplantation has become a highly standardized, acceptable option for selected patients with end-stage liver disease and/or hepatocellular carcinoma in the setting of cirrhosis. Both conditions are associated with loss of skeletal muscle mass (sarcopenia) and physical deconditioning. Both conditions result in a dramatic decrease in the patients' quality of life, negatively impacting on the pre- and posttransplant prognosis. In this context, awareness of the advantages of physical activity in both the pre- and post-transplant setting is key. However, the importance of regular, individualized and patient-adapted physical activity is still understudied and underestimated. This article describes a three-sided perspective on the importance of physical activity in the setting of liver transplantation, including a patient's, transplant surgeon's and hepatologist's point of view.
\end{abstract}

Enhanced digital features To view enhanced digital features for this article go to https://doi.org/10.6084/ m9.figshare.7093529.

L. Beekman · A. Berzigotti $(\bowtie) \cdot$ V. Banz

Department for Visceral Surgery and Medicine, Bern

University Hospital and University of Bern, Bern,

Switzerland

e-mail: annalisa.berzigotti@insel.ch
Keywords: Exercise; Liver cirrhosis; Liver transplantation; Malnutrition; Physical activity; Reconditioning; Sarcopenia

\section{INTRODUCTION}

Liver transplantation (OLT) has become a highly standardized, acceptable option for selected patients with severe complications of liver disease. Reduction in skeletal muscle mass (sarcopenia) and function (physical deconditioning) are highly prevalent in patients on the waiting list for liver transplantation. They result in a dramatic decrease in the patients' quality of life, also negatively impacting the pre- and posttransplant prognosis. Awareness of the benefits of physical activity in both the pre- (pre-conditioning) and post-transplant setting is increasing among the medical community. However, the importance of regular, individualized and patient-adapted physical activity is still understudied and underestimated, and it is certainly not yet fully perceived as part of the therapy by most of the patients. In this article, we discuss the importance of physical activity in the setting of liver transplantation by presenting a three-sided perspective including a patient's, transplant surgeon's and hepatologist's point of view. 


\section{PATIENT'S EXPERIENCE}

After having learned from my transplant surgeon on October 14th, 2013, that my liver transplantation had been successful, I could not have been a happier person. On the other hand, I was lying on the intensive care unit on strong drugs and in a lot of pain, wondering how I would ever be able to sit up or even get out of bed again.

Since I was a child, I have enjoyed a variety of sports from figure skating to tap dancing and now golf. Having lived through various difficult health issues (complications of portal hypertension due to portal vein thrombosis since I was 13 years old and liver adenomatosis with acute bleeding due to rupture at the age of 42 , eventually leading to liver transplantation; placenta percreta at the age of 32), I have had to get up again and again after having being knocked back numerous times. I therefore strongly believe and have experienced that keeping active and fit helps people get through illness and surgery more easily and successfully.

My first sports achievement after my liver transplant in 2013 was my daily staircase climb in the hospital, which was important to get me strong enough to go home. I felt awful and it was hard work, but I tried to make small improvements from 1 day to the next.

After returning home 10 days post-transplant, reality kicked in. I still had a long way to go to feel strong enough to lead an active family life. The first weeks and months at home were tough because of the postoperative pain as well as pain in numerous other muscles throughout the body and side effects from various medications. Looking back, I now realize that I definitely would have benefitted from early professional support on how to improve my physical activity and how to go about these first steps.

As an active working mother with three teenagers, it is important that I contribute as much as possible towards counteracting the possible side effects of immunosuppression (e.g. diabetes, high blood pressure, overweight, de novo tumors, etc.) [1]. Regular physical activity is one of the best ways to help avoid these chronic diseases while at the same time improving physical and mental wellbeing and achieving a good quality of life [2]. According to the current state of research, specialists agree that regular exercise plays an extremely important role before and after organ transplantation in order to have a good quality of life with minimal restrictions and few chronic diseases [3]. Currently, many European liver transplant clinics inform their liver patients about the importance and need for regular physical activity. However, in most cases a brief verbal encouragement or written information in a booklet is not enough to achieve a lasting effect in these patients. How they can be motivated to carry out regular physical activity with a lasting effect is still under-researched, and there are currently not enough scientifically substantiated foundations with matching long-term controls on this topic.

I wanted to know more about this and wanted to engage in the change needed to improve the current situation. Two years posttransplant, I started my EMBA (Executive Master in Business Administration) training in health care economics and management and decided to devote part of it to the topic of physical activity of liver transplant patients.

I carried out a qualitative study including interviews with transplant experts in order to provide qualitative results and recommendations for the education and monitoring of physical activity of liver transplant patients. As a first step, the study included a comprehensive literature search and a search for best practice inputs from other transplant clinics. In a next step, the topics and questions for the expert interviews were validated by numerous Swiss and international transplant specialists using an online tool. The results of the study provided valuable input regarding open issues, e.g., at what time, with which content, by which specialists and with what kind of tools liver patients should be instructed before and after a liver transplant for physical activity. In addition, which barriers need to be considered and how the physical activity and its effect on the patients can be controlled and measured were shown. This led to the design of a pilot project (Fig. 1) that is now entering a more detailed 


\begin{tabular}{|c|c|c|c|c|c|}
\hline $\begin{array}{l}\text { Phase } 1 \\
\text { Pre-transplant }\end{array}$ & & $\begin{array}{l}\text { Phase } 2 \\
\text { Post-transplant }\end{array}$ & $\begin{array}{l}\text { Phase } 3 \\
\text { Post-transplant }\end{array}$ & $\begin{array}{l}\text { Phase } 4 \\
\text { Post-transplant }\end{array}$ & $\begin{array}{l}\text { Phase } 5 \\
\text { Post-transplant }\end{array}$ \\
\hline Prehabilitation & LTX & Hospital Stay & 3 weeks - 3 months & 3- 6 months & Longterm \\
\hline $\begin{array}{l}\text { - First information/ } \\
\text { education to patient, } \\
\text { hand out a brochure } \\
\text { - Evaluation of level of } \\
\text { physical activity, or } \\
\text { health status (e.g., Duke } \\
\text { Activity Status Index) } \\
\text { - Define goals of pre- } \\
\text { habilitation individually: } \\
\text { what, how and where, } \\
\text { how often? } \\
\text { - Close control and } \\
\text { adjustment of goals } \\
\text { - Goal: prevention of } \\
\text { muscle loss and } \\
\text { contribution to minimize } \\
\text { the complications of } \\
\text { liver transplantation }\end{array}$ & $\frac{5}{\frac{5}{0}}$ & $\begin{array}{l}\text { - Physiotherapy for the } \\
\text { first mobilization of the } \\
\text { patient (breathing, } \\
\text { sitting up, walking, } \\
\text { stair climbing) } \\
\text { - Evaluation of the } \\
\text { physical condition to } \\
\text { plan the postoperative } \\
\text { physical activity } \\
\text { - Arrange first post- } \\
\text { discharge } \\
\text { appointment with } \\
\text { physiotherapy before } \\
\text { the patient leaves the } \\
\text { hospital } \\
\text { - In case of inadequate } \\
\text { physical condition, } \\
\text { evaluation and } \\
\text { clarification on how to } \\
\text { conduct a } \\
\text { rehabilitation }\end{array}$ & $\begin{array}{l}\text { - Individual } \\
\text { Physiotherapy with } \\
\text { gentle strengthening } \\
\text { with the aim of } \\
\text { returning to an } \\
\text { independent everyday } \\
\text { life } \\
\text { - Defining of individual } \\
\text { goals for physical } \\
\text { activity: What, how } \\
\text { and where, how often? } \\
\text { - Close monitoring and } \\
\text { adjustment of goals if } \\
\text { necessary } \\
\text { - Avoidance of } \\
\text { strenuous activity until } \\
\text { wound healing is } \\
\text { completed to reduce } \\
\text { risk of postoperative } \\
\text { wound dehiscence / } \\
\text { incisional hernia } \\
\text { formation }\end{array}$ & $\begin{array}{l}\text { - Change from individual } \\
\text { physiotherapy to group } \\
\text { physiotherapy, program } \\
\text { with personal trainer or } \\
\text { even independent } \\
\text { activities } \\
\text { - Continue to promote } \\
\text { endurance and muscle } \\
\text { growth } \\
\text { - Monthly control and } \\
\text { adjustment of goals } \\
\text { - Aim, to slowly transfer } \\
\text { the responsibility of the } \\
\text { professionals to the liver } \\
\text { transplant patients } \\
\text { - Offer consultation «what } \\
\text { sport suits me?» }\end{array}$ & $\begin{array}{l}\text { - Patient takes over } \\
\text { responsibility for his } \\
\text { regular physical } \\
\text { activity and } \\
\text { implements it } \\
\text { - Information about } \\
\text { Transplant Games } \\
\text { and "Fit for Life" } \\
\text { initiative } \\
\text { - Support by specialists } \\
\text { only on-demand } \\
\text { - Monitoring of physical } \\
\text { activity lifelong at } \\
\text { least twice a year } \\
\text { (GPs; hepatologists) } \\
\text { - If necessary, } \\
\text { re-prescription of } \\
\text { physiotherapy, e.g. } \\
\text { physical activity }\end{array}$ \\
\hline \multicolumn{6}{|c|}{$\begin{array}{l}\text { Interdisciplinary Team of Experts: Transplant surgeons, Hepatologists, Physiotherapists, Transplant coordinators, Transplant } \\
\text { nurses and Advanced Practice Nurses, Nutritional Consultant }\end{array}$} \\
\hline
\end{tabular}

Fig. 1 Planned program of physical activity pre- and post-liver transplantation at our center

planning phase and hopefully will be implemented soon at our hospital, where I too was transplanted.

In parallel, I started exercising on a regular basis and began participating in the Transplant Games (Fig. 2). To take part in the World and European Transplant Games was an important goal after my liver transplantation and helped me get physically active and fit again. Not only are the Transplant Games a great motivation to keep up regular physical activity but also a great opportunity to meet and talk to other inspiring transplant patients who have been through similar experiences [4].

\section{SURGEON'S EXPERIENCE}

While most surgical techniques are becoming increasingly minimally invasive and less traumatic than they were a few decades ago, orthotopic liver transplantation (OLT) still remains a major abdominal intervention, carrying with it all the problems associated with such extensive surgery. There is evidence that patients requiring elective intracavity surgery profit from so-called prehabilitation with increased preoperative fitness levels [5]. The link to the reduction in postoperative morbidity and mortality however remains weak. Nevertheless, a more recent randomized, blinded, controlled trial evaluating the effects of individualized prehabilitation in high-risk patients undergoing elective major abdominal surgery showed a 50\% reduction in the number of patients suffering from postoperative complications as well as a significant reduction in the overall rate of postoperative complications [6].

With increasing numbers of patients on the liver transplant waiting lists and a worldwide shortage of donor organs, in many countries patients wait long before receiving a new liver (median of about 12 months in Europe) [7].

In Switzerland, most patients will wait for over 12 months before finally getting a new liver. During this time, many will be in and out of the hospital because of complications associated with end-stage liver disease, resulting in an exacerbation of their general deconditioning. 


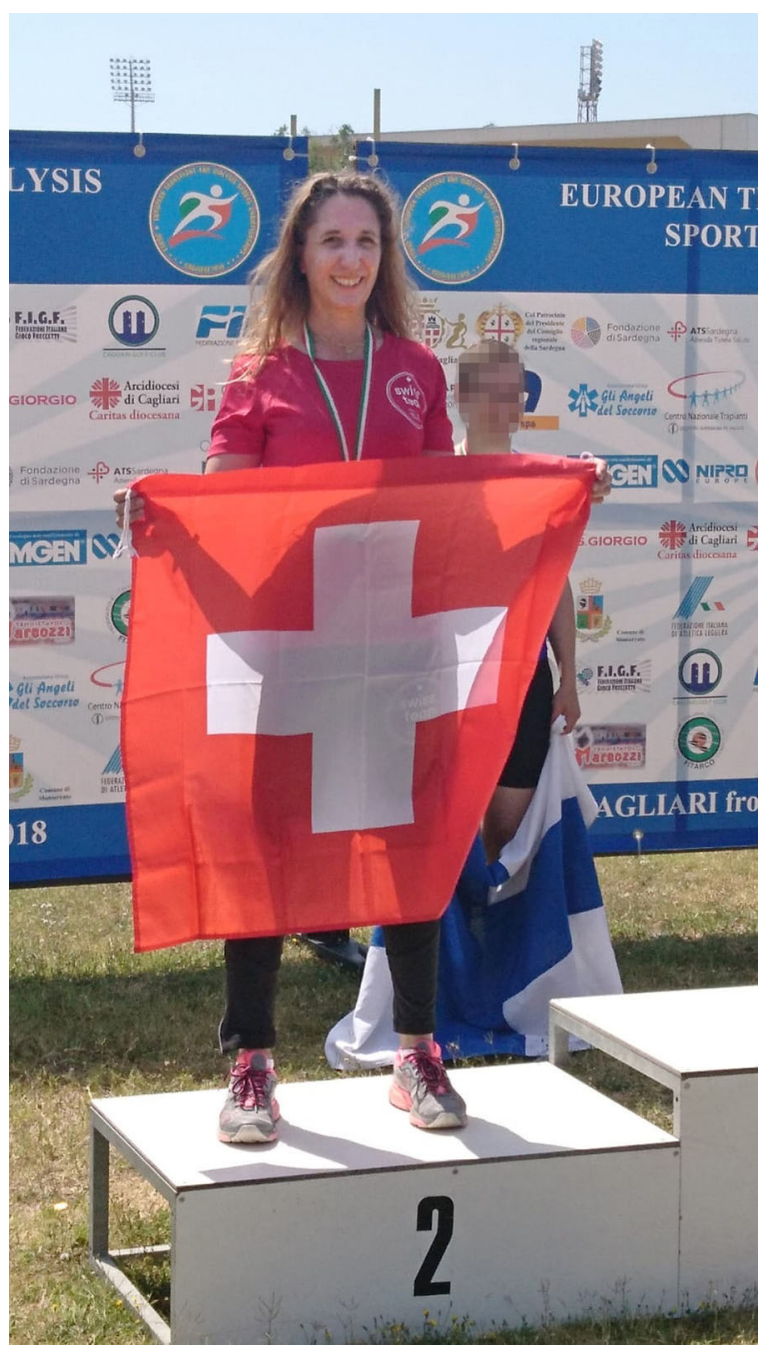

Fig. 2 Mrs. Beekman silver medal in long jump at the 2018 European Transplant Games in Cagliari, Italy

Deconditioning combined with general frailtyas is commonly seen in this patient population-may have a detrimental effect not only in the perioperative setting but also in the long term. Indeed, the effect of preoperative frailty on postoperative outcome is currently being evaluated in many different post-surgical/postinterventional settings, and a recent study by Lai et al. was able to show that even in the setting of a successful OLT, only two out of five patients will eventually achieve robustness 1 year posttransplant [8]. This is all the more worrying when considering the fact that even the seemingly "better off" Child A patients primarily receiving an OLT for hepatocellular carcinoma suffer from an equally relevant reduction in general health status in the short and long term compared with the obviously frail patients. This clearly shows the importance of implementing a routine preoperative training program for all the patients on the liver transplant waiting list if complication rates and hospital length of stay are to be reduced in the short term and quality of life and general robustness are to be increased in the long term.

\section{HEPATOLOGIST'S EXPERIENCE}

The return to a normal life is the aim of medicine in general and of any organ transplantation. As outlined by my colleague transplant surgeon above, before undergoing OLT, most patients experience severe fatigue, protein-energy malnutrition due to hypercatabolism and consequently sarcopenia and deconditioning (decreased muscle strength, endurance and oxygen uptake) [9]. Importantly, even patients who are obese before OLT suffer from these conditions, presenting with so-called "sarcopenic obesity" [10]. Recovery of muscle mass and function after transplantation is favored by the normalization of liver function. However, without specific measures, this takes a long time, during which patients are limited in their daily life. In addition, studies demonstrate that even in the setting of successful transplantation, deconditioning persists long term for not yet fully clarified reasons [11, 12]. Post-transplant, patients may go back to taking on a sedentary life, something which by most may be perceived as "normal." Currently, life expectancy of patients after OLT is excellent, with a 90\% 1-year and over 70\% 5-year survival. Five-year survival is expected to further improve in the near future, given that effective therapies for hepatitis $C$ virus (representing the main negative prognostic factor after OLT) are now available [7]. Long-term complications after OLT are mostly related to cardiovascular events and cancer. Up to $58 \%$ of patients develop cardiovascular risk factors or metabolic syndrome (elevated arterial blood pressure, diabetes, atherogenic dyslipidemia and obesity) [13], 
which are in part due to the use of immunosuppressant medication such as calcineurin inhibitors and/or mTOR inhibitors [14]. Not surprisingly, and similarly to what is observed in the general population, the presence of obesity and a metabolic syndrome increases the risk of stroke, myocardial infarction as well as chronic renal failure and de novo malignancies in OLT patients [15]. Modifying these risk factors thus favorably impacts the long-term prognosis of patients post-OLT. Importantly, exercise alone proved effective in reducing the onset of metabolic syndrome after OLT in two studies $[13,16]$. In addition, physical activity dramatically improves quality of life in this setting, with a strong correlation between level of fitness/physical activity and quality of life [16-20]. Nonetheless, only one quarter of patients are physically active after transplantation [16]. Large randomized controlled studies in this field are lacking. However, in view of the existing evidence, the European Association for the Study of the Liver (EASL) recommends that physical activity should be proposed as part of the therapeutic regimen after OLT [21].

\section{DISCUSSION AND NEXT STEPS}

Improving physical activity for patients undergoing OLT is a challenge at many different levels. It is a challenge for the medical community since it requires an interdisciplinary team effort implying the integration of new specialists (such as sports medicine specialists) in the existing liver transplantation process as well as intensified communication between medical specialists and family physicians. It is a challenge for the health system as it implies using resources to focus on prevention and the organization of a network between hospitals and private, non-hospital-based facilities. It is, of course, also a challenge for the patients, to whom we need to listen carefully in order to adapt physical activity programs. This might be particularly true for women, who due to marital and parental duties might be disadvantaged in undertaking physical activities, something very relevant in certain cultures. Patients need to be supported and empowered (barriers and motivation) at the same time in order for them to be able to care for their physical activity in the long term. New physical activity programs also need to adhere to sustainability and safety principles, with a continuous evaluation of clinical and quality of life end points. Several questions still need to be clarified by future research: when should patients start their training? Which kind of training is best? What are the best end points to use in trials concerning physical activity in liver transplantation?

Our team in Bern is convinced that all these financial, organizational and cultural challenges are worth embracing and research aimed at answering the above-mentioned questions is essential and worthwhile. Our team is working on setting up a program integrating patientadapted physical activity into the liver transplant program routine. As Lara's example brilliantly shows, physical activity is a powerful tool to help patients prepare for liver transplantation and return back to a normal, healthy and fulfilling life post-transplant.

\section{ACKNOWLEDGEMENTS}

Funding. No funding or sponsorship was received for this study or publication of this article.

Authorship. All named authors meet the International Committee of Medical Journal Editors (ICMJE) criteria for authorship for this article, take responsibility for the integrity of the work as a whole and have given their approval for this version to be published.

Disclosures. Lara Beekman, Annalisa Berzigotti and Vanessa Banz have nothing to disclose.

Compliance with Ethics Guidelines. Informed consent was obtained from all individuals for whom identifying information is included in this article. 
Open Access. This article is distributed under the terms of the Creative Commons Attribution-NonCommercial 4.0 International License (http://creativecommons.org/licenses/ by-nc/4.0/), which permits any noncommercial use, distribution, and reproduction in any medium, provided you give appropriate credit to the original author(s) and the source, provide a link to the Creative Commons license, and indicate if changes were made.

\section{REFERENCES}

1. Yang LS, Shan LL, Saxena A, Morris DL. Liver transplantation: a systematic review of long-term quality of life. Liver Int. 2014;34:1298-313.

2. Warburton DE, Nicol CW, Bredin SS. Health benefits of physical activity: the evidence. CMAJ. 2006;174:801-9.

3. Gustaw T, Schoo E, Barbalinardo C, Rodrigues N, Zameni Y, Motta VN, Mathur S, et al. Physical activity in solid organ transplant recipients: participation, predictors, barriers, and facilitators. Clin Transplant. 2017;31:e12929.

4. Slapak M. Sport and transplantation. Ann Transplant. 2005;10:60-7.

5. O'Doherty AF, West M, Jack S, Grocott MP. Preoperative aerobic exercise training in elective intracavity surgery: a systematic review. Br J Anaesth. 2013;110:679-89.

6. Barberan-Garcia A, Ubre M, Roca J, Lacy AM, Burgos F, Risco R, Momblan D, et al. Personalised prehabilitation in high-risk patients undergoing elective major abdominal surgery: a randomized blinded controlled trial. Ann Surg. 2018;267:50-6.

7. Eurotransplant. Statistical report 2017. https:// www.eurotransplant.org/cms/mediaobject.php? file $=803150+020288+$ Statistical + Report $+2017+\%$ 28online\%295.pdf. Accessed 4 July 2018.

8. Lai JC, Segev DL, McCulloch CE, Covinsky KE, Dodge JL, Feng S. Physical frailty after liver transplantation. Am J Transpl. 2018;18(8):1986-94.

9. Duarte-Rojo A, Ruiz-Margain A, Montano-Loza AJ, Macias-Rodriguez RU, Ferrando A, Kim WR. Exercise and physical activity for patients with endstage liver disease: improving functional status and sarcopenia while on the transplant waiting list. Liver Transpl. 2018;24:122-39.
10. Montano-Loza AJ, Angulo P, Meza-Junco J, Prado CM, Sawyer MB, Beaumont C, Esfandiari N, et al. Sarcopenic obesity and myosteatosis are associated with higher mortality in patients with cirrhosis. J Cachexia Sarcopenia Muscle. 2016;7:126-35.

11. Beyer N, Aadahl M, Strange B, Kirkegaard P, Hansen BA, Mohr T, Kjaer M. Improved physical performance after orthotopic liver transplantation. Liver Transpl Surg. 1999;5:301-9.

12. Krasnoff JB, Vintro AQ, Ascher NL, Bass NM, Paul SM, Dodd MJ, Painter PL. A randomized trial of exercise and dietary counseling after liver transplantation. Am J Transpl. 2006;6:1896-905.

13. Kallwitz ER, Loy V, Mettu P, Von Roenn N, Berkes J, Cotler SJ. Physical activity and metabolic syndrome in liver transplant recipients. Liver Transpl. 2013;19:1125-31.

14. Fussner LA, Heimbach JK, Fan C, Dierkhising R, Coss E, Leise MD, Watt KD. Cardiovascular disease after liver transplantation: when, what, and who is at risk. Liver Transpl. 2015;21:889-96.

15. Richards J, Gunson B, Johnson J, Neuberger J. Weight gain and obesity after liver transplantation. Transpl Int. 2005;18:461-6.

16. Painter P, Krasnoff J, Paul SM, Ascher NL. Physical activity and health-related quality of life in liver transplant recipients. Liver Transpl. 2001;7:213-9.

17. Masala D, Mannocci A, Unim B, Del Cimmuto A, Turchetta F, Gatto G, Santoro R, et al. Quality of life and physical activity in liver transplantation patients: results of a case-control study in Italy. Transpl Proc. 2012;44:1346-50.

18. Rongies W, Stepniewska S, Lewandowska M, Smolis-Bak E, Dolecki W, Sierdzinski J, Trzepla E, et al. Physical activity long-term after liver transplantation yields better quality of life. Ann Transpl. 2011;16:126-31.

19. van den Berg-Emons R, Kazemier G, van Ginneken B, Nieuwenhuijsen C, Tilanus H, Stam H. Fatigue, level of everyday physical activity and quality of life after liver transplantation. J Rehabil Med. 2006;38:124-9.

20. van Ginneken BT, van den Berg-Emons RJ, Kazemier G, Metselaar HJ, Tilanus HW, Stam HJ. Physical fitness, fatigue, and quality of life after liver transplantation. Eur J Appl Physiol. 2007;100:345-53.

21. European Association for the Study of the Liver. Electronic address eee. EASL clinical practice guidelines: liver transplantation. J Hepatol. 2016;64:433-85. 